\title{
Cu2O epitaxial films with domain structures prepared on Y- stabilized ZrO2 substrates by pulsed laser deposition
}

DOI:

10.1016/j.ceramint.2017.08.098

\section{Document Version}

Accepted author manuscript

Link to publication record in Manchester Research Explorer

\section{Citation for published version (APA):}

Liu, X., Xu, M., Ma, J., Zhang, X., Luan, C., Feng, X., \& Song, A. (2017). Cu,O epitaxial films with domain structures prepared on $\mathrm{Y}$-stabilized $\mathrm{ZrO}$, substrates by pulsed laser depositfon. Ceramics International, 43(17), 15500-15504. https://doi.org/10.1016/j.ceramint.2017.08.098

\section{Published in:}

Ceramics International

\section{Citing this paper}

Please note that where the full-text provided on Manchester Research Explorer is the Author Accepted Manuscript or Proof version this may differ from the final Published version. If citing, it is advised that you check and use the publisher's definitive version.

\section{General rights}

Copyright and moral rights for the publications made accessible in the Research Explorer are retained by the authors and/or other copyright owners and it is a condition of accessing publications that users recognise and abide by the legal requirements associated with these rights.

\section{Takedown policy}

If you believe that this document breaches copyright please refer to the University of Manchester's Takedown Procedures [http://man.ac.uk/04Y6Bo] or contact uml.scholarlycommunications@manchester.ac.uk providing relevant details, so we can investigate your claim.

\section{OPEN ACCESS}




\title{
$\mathrm{Cu}_{2} \mathrm{O}$ epitaxial films with domain structures prepared on Y-stabilized $\mathrm{ZrO}_{2}$ substrates by pulsed laser deposition
}

\author{
Xiaohui Liu ${ }^{\mathrm{a}}$, Meng Xu' ${ }^{\mathrm{a}}$, Jin Ma ${ }^{\mathrm{a}}$, Xijian Zhang ${ }^{\mathrm{a}}$, Caina Luan ${ }^{\mathrm{a}}$, Xianjin Feng ${ }^{\mathrm{a}, *}$, Aimin \\ Song $^{\mathrm{a}, \mathrm{b}, *}$ \\ ${ }^{\mathrm{a} C e n t e r}$ of Nanoelectronics and School of Microelectronics, Shandong University, Jinan 250100, \\ China \\ ${ }^{\mathrm{b}}$ School of Electrical and Electronic Engineering, University of Manchester, Manchester M13 9PL, \\ United Kingdom
}

\begin{abstract}
Copper oxide films have been deposited on the Y-stabilized $\mathrm{ZrO}_{2}$ (YSZ) (100) substrates by pulsed laser deposition and the effect of oxygen pressure $\left(\mathrm{P}_{\mathrm{O}_{2}}\right)$ on the film properties was investigated in detail. The phase, crystallinity, and surface morphology of the films were strongly influenced by $\mathrm{P}_{\mathrm{O}_{2}}$ and the film prepared at $0.09 \mathrm{~Pa}$ was pure cuprous oxide $\left(\mathrm{Cu}_{2} \mathrm{O}\right)$ having the best film crystallinity. An out-of-plane epitaxial relationship of $\mathrm{Cu}_{2} \mathrm{O}(110) / / \mathrm{YSZ}$ (100) with six different kinds of domain structure were observed for the 0.09 Pa-deposited sample and the corresponding in-plane epitaxial relationships were deduced. The lowest resistivity of $13.4 \Omega \cdot \mathrm{cm}$ and highest Hall mobility of $16.3 \mathrm{~cm}^{2} \cdot \mathrm{v}^{-1} \cdot \mathrm{s}^{-1}$ were also obtained for the film deposited at $0.09 \mathrm{~Pa}$. The optical band gap of the as-prepared copper oxide films varied from 2.37 to $2.57 \mathrm{eV}$.
\end{abstract}

Keywords: Epitaxial growth; Cuprous oxide; Electrical properties; Pulsed laser deposition

\footnotetext{
*Corresponding authors: Tel.: +86 53188363606 ; fax: +86 53188564886.

E-mail addresses: xianjinfeng@sdu.edu.cn (X. Feng), A.song@manchester.ac.uk (A. Song).
} 


\section{Introduction}

As a p-type semiconductor with a direct band gap of 2.0-2.6 eV [1-5] and a maximum hole mobility exceeding $100 \mathrm{~cm}^{2} \cdot \mathrm{V}^{-1} \cdot \mathrm{s}^{-1}$ [6], cuprous oxide $\left(\mathrm{Cu}_{2} \mathrm{O}\right)$ has been considered as a promising candidate for applications in solar cells due to its abundance, nontoxicity and large optical absorption coefficient [1, 7]. There have been many reports on $\mathrm{Cu}_{2} \mathrm{O}$-based solar cells [8-10]. Until now, the highest reported conversion efficiency of $\mathrm{Cu}_{2} \mathrm{O}$ solar cells was around $6.1 \%$ with a $\mathrm{MgF}_{2} / \mathrm{AZO} / \mathrm{AlGaO} / \mathrm{Cu}_{2} \mathrm{O}: \mathrm{Na}$ heterojunction structure formed on the thermally oxidized $\mathrm{Cu}$ sheets [10], while the maximum theoretical energy conversion efficiency of a solar cell fabricated using $\mathrm{Cu}_{2} \mathrm{O}$ as the active layer is $20 \%$ [11]. The unsatisfactory photovoltaic performance of $\mathrm{Cu}_{2} \mathrm{O}$-based solar cells are mostly due to the difficulties in synthesizing high quality $\mathrm{Cu}_{2} \mathrm{O}$ films with proper electrical properties of both low electrical resistivity and high mobility. Therefore, to further improve the performance of $\mathrm{Cu}_{2} \mathrm{O}$-based solar cells, it is necessary to obtain high quality $\mathrm{Cu}_{2} \mathrm{O}$ films with well controlled orientation, microstructure and electrical properties [12].

Many methods have been used to prepare $\mathrm{Cu}_{2} \mathrm{O}$ films such as sputtering [3], thermal oxidation [8], evaporation [5], molecular beam epitaxy [13], and electrodeposition [9]. But up to now, only a few studies were reported on the growth of $\mathrm{Cu}_{2} \mathrm{O}$ films by pulsed laser deposition (PLD) [12, 14-18], which could deposit highly oriented crystalline films at low substrate temperatures due to the high kinetic energy of the ionized and ejected species in the laser produced plasma. Especially, the 
effect of oxygen pressure $\left(\mathrm{P}_{\mathrm{O}_{2}}\right)$ during the deposition on the film properties was rarely studied $[15,16]$. In addition, various substrates such as $\mathrm{MgO}[12], \mathrm{ZnO}[19], \mathrm{GaN}$ [20], $\mathrm{SrTiO}_{3}[14]$ and $\mathrm{Al}_{2} \mathrm{O}_{3}$ [21] have been implemented for the $\mathrm{Cu}_{2} \mathrm{O}$ growth, among which $\mathrm{MgO}$ having a cubic lattice and a small lattice mismatch with $\mathrm{Cu}_{2} \mathrm{O}$ was the most commonly used substrate to prepare high quality $\mathrm{Cu}_{2} \mathrm{O}$ epitaxial films. However, $\mathrm{MgO}$ is also known to be unstable in air if exposed for a prolonged period of time which can cause huge problems with the reproducibility of the growth on such surfaces [22]. The Y-stabilized $\mathrm{ZrO}_{2}$ (YSZ) substrate with a cubic lattice could be a candidate to grow high quality $\mathrm{Cu}_{2} \mathrm{O}$ films for its high optical transmittance, high thermal resistivity and excellent corrosion and erosion resistance [23-25]. However, until now, there are very few reports on the growth of $\mathrm{Cu}_{2} \mathrm{O}$ films on $\mathrm{YSZ}$ substrates [26], and especially the epitaxial growth of $\mathrm{Cu}_{2} \mathrm{O}$ films on $\mathrm{YSZ}$ substrates has never been reported. Furthermore, the reported $\mathrm{Cu}_{2} \mathrm{O}$ films grown by PLD usually had high electrical resistivities due to the difficulties in simultaneously achieving relatively high carrier concentration and mobility [16-18], which strongly restricts their applications in $\mathrm{Cu}_{2} \mathrm{O}$ solar cells.

In this study, copper oxide films were deposited on YSZ (100) substrates by PLD and the influence of oxygen pressure on the structural, morphological, electrical and optical properties of the films was investigated. The $\mathrm{Cu}_{2} \mathrm{O}$ epitaxial film having six different kinds of domain structure is reported, which exhibits a low resistivity of 13.4 $\Omega \cdot \mathrm{cm}$ and a high Hall mobility of $16.3 \mathrm{~cm}^{2} \cdot \mathrm{v}^{-1} \cdot \mathrm{s}^{-1}$ that are quite suitable for photovoltaic applications. 


\section{Experimental}

Copper oxide films were grown by PLD using a $\mathrm{KrF}$ excimer laser (wavelength: $248 \mathrm{~nm}$ ) and $\mathrm{Cu}_{2} \mathrm{O}$ ceramic target (purity: $4 \mathrm{~N}$ ). The pulse duration and frequency were $20 \mathrm{~ns}$ and $20 \mathrm{~Hz}$, respectively. The YSZ (100) single crystals were used as the substrates after a four-step ultrasonic cleaning in 5\% Decon 90 aqueous solution, deionized water, acetone and anhydrous ethanol for 5, 10, 5 and 5 min., respectively. The laser power density was $\sim 6 \mathrm{~J} / \mathrm{cm}^{2}$ at the target surface, which yielded a film growth rate of $\sim 7 \mathrm{~nm} / \mathrm{min}$. The substrate temperature was maintained at $600^{\circ} \mathrm{C}$ and the $\mathrm{P}_{\mathrm{O}_{2}}$ during deposition varied from 0.02 to $0.12 \mathrm{~Pa}$ with a base pressure under $10^{-4} \mathrm{~Pa}$.

The crystalline quality and epitaxial relationship were determined by the $\theta-2 \theta$ and in-plane $\Phi$-scans using the Rigaku and Philips X'Pert PRO X-ray diffractometers (XRD), respectively. High resolution transmission electron microscopy (HRTEM) and selected-area electron diffraction (SAED) were used to observe the atomic arrangements across the substrate-film interface with a Tecnai F30 transmission electron microscope operated at $300 \mathrm{kV}$. The surface morphology was observed by a FEI Nova NanoSEM 450 field emission scanning electron microscope (SEM). The room temperature micro-Raman spectroscopy ( $\mu \mathrm{RS})$ analyses were carried out employing a Renishaw inVia Reflex Raman system with a $532 \mathrm{~nm}$ laser. The electrical properties were measured by Van der Pauw method. The optical transmittance was measured using a TU-1901 double-beam UV-vis-NIR spectrophotometer. 


\section{Results and discussion}

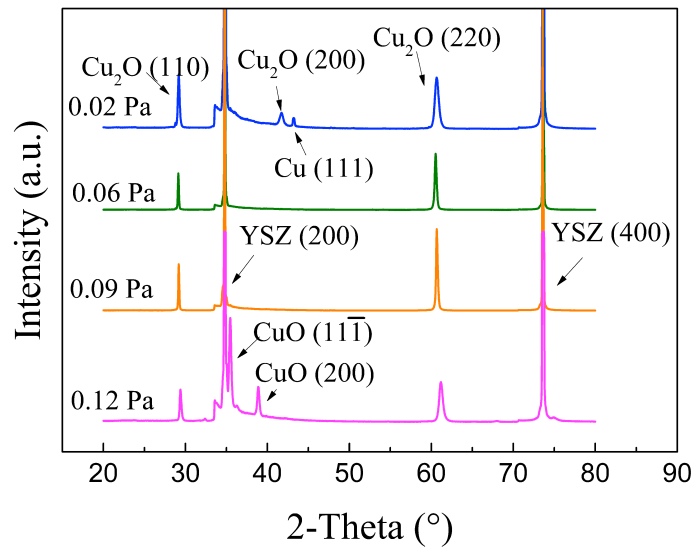

Fig. 1 XRD patterns of copper oxide films grown on YSZ (100) substrates under different oxygen pressures.

Typical XRD patterns of $\theta-2 \theta$ scan for the copper oxide films prepared under different oxygen pressures are shown in Fig. 1. In addition to the substrate diffraction peaks of YSZ (200) and (400) located respectively at $34.9^{\circ}$ and $73.6^{\circ}$ (JCPDS No.30-1468), four other peaks can be observed at $0.02 \mathrm{~Pa}$, which are identified as $\mathrm{Cu}_{2} \mathrm{O}(110), \mathrm{Cu}_{2} \mathrm{O}(200), \mathrm{Cu}(111)$ and $\mathrm{Cu}_{2} \mathrm{O}(220)$ located at $29.2^{\circ}, 41.7^{\circ}, 43.2^{\circ}$ and 60.6 ${ }^{\circ}$ (JCPDS No.65-3288 for $\mathrm{Cu}_{2} \mathrm{O}$, No.04-0836 for $\mathrm{Cu}$ ), respectively, corresponding to a mixed phase of $\mathrm{Cu}_{2} \mathrm{O}$ and $\mathrm{Cu}$. As the $\mathrm{P}_{\mathrm{O}_{2}}$ increases to 0.06 and $0.09 \mathrm{~Pa}$, the $\mathrm{Cu}$ (111) and $\mathrm{Cu}_{2} \mathrm{O}(200)$ peaks are absent, indicating that pure phase $\mathrm{Cu}_{2} \mathrm{O}$ with a single orientation along (110) is obtained. The full widths at half maximum (FWHMs) of the $\mathrm{Cu}_{2} \mathrm{O}$ (110) peak are $0.143^{\circ}$ and $0.141^{\circ}$ for the samples grown at 0.06 and $0.09 \mathrm{~Pa}$, respectively, indicating a better crystalline quality of the $\mathrm{Cu}_{2} \mathrm{O}$ film deposited at 0.09 $\mathrm{Pa}$. As the $\mathrm{P}_{\mathrm{O}_{2}}$ increases further to $0.12 \mathrm{~Pa}$, the $\mathrm{CuO}(11 \overline{1})$ and $\mathrm{CuO}$ (200) peaks 
located respectively at $35.5^{\circ}$ and $38.9^{\circ}$ (JCPDS No.48-1548) show up, indicating a mixed phase of $\mathrm{Cu}_{2} \mathrm{O}$ and $\mathrm{CuO}$ and the degradation of film crystallinity. The XRD results reveal that the crystalline quality of copper oxide films is strongly affected by oxygen pressure and the film prepared at $0.09 \mathrm{~Pa}$ has the best crystallinity with an out-of-plane epitaxial relationship of $\mathrm{Cu}_{2} \mathrm{O}(110) / / \mathrm{YSZ}$ (100).
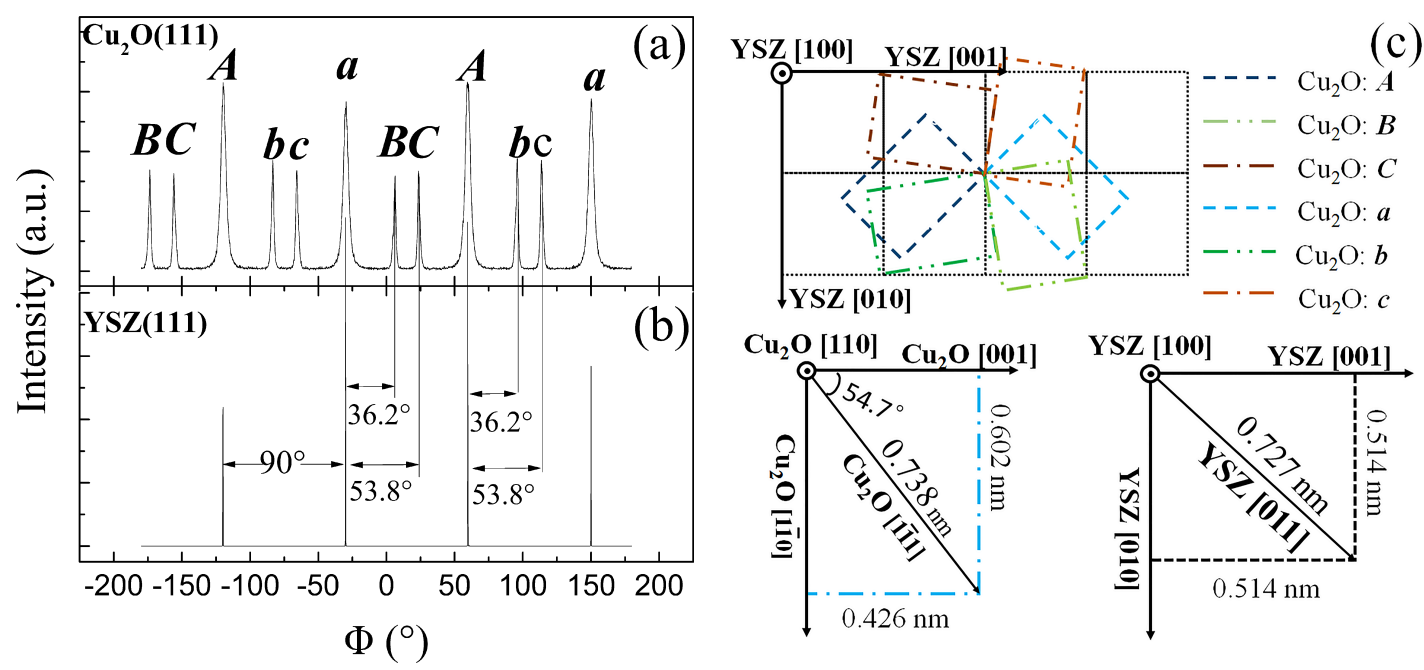

Fig. 2. XRD patterns of off-specular $\Phi$-scan for the (a) $\mathrm{Cu}_{2} \mathrm{O}\{111\}$ and (b) YSZ $\{111\}$ planes of the sample grown under $\mathrm{P}_{\mathrm{O}_{2}}$ of $0.09 \mathrm{~Pa}$. (c) Proposed in-plane epitaxial relationships between the $\mathrm{Cu}_{2} \mathrm{O}$ film and $\mathrm{YSZ}$ substrate.

Fig. 2(a) shows the off-specular $\Phi$-scan of $\mathrm{Cu}_{2} \mathrm{O}\{111\}$ planes $\left(\Psi=35.26^{\circ}\right)$ for the film deposited under $\mathrm{P}_{\mathrm{O}_{2}}$ of $0.09 \mathrm{~Pa}$. As we know, the $\{111\}$ plane of $\mathrm{Cu}_{2} \mathrm{O}$ is two-fold symmetrical along $\mathrm{Cu}_{2} \mathrm{O}$ [110]. However, twelve diffraction peaks are clearly observed in Fig. 2(a), which indicate the existence of six different kinds of domain structure as labeled respectively by $\boldsymbol{A}, \boldsymbol{a}, \boldsymbol{B}, \boldsymbol{b}, \boldsymbol{C}$, and $\boldsymbol{c}$ inside the film. Fig. 2(b) shows the off-specular $\Phi$-scan of YSZ $\{111\}$ planes $\left(\Psi=54.73^{\circ}\right)$ for the substrate, 
from which four diffraction peaks separated by $90^{\circ}$ with the same $\Phi$-angles as the $\mathrm{Cu}_{2} \mathrm{O}\{111\}$ planes could be seen. The proposed in-plane epitaxial relationships between the $\mathrm{Cu}_{2} \mathrm{O}$ film and YSZ substrate deduced from Fig. 2(a) and (b) are schematically shown in Fig. 2(c). The commercially available YSZ substrate we used has a cubic structure with the lattice parameter of $5.14 \AA$, and the cubic $\mathrm{Cu}_{2} \mathrm{O}$ has a lattice parameter of $4.26 \AA$. As shown in Fig. 2(c), two domains have the in-plane epitaxial relationships of $\boldsymbol{A}: \mathrm{Cu}_{2} \mathrm{O}[001] / / Y S Z$ [011] and $\boldsymbol{a}: \mathrm{Cu}_{2} \mathrm{O}[001] / / \mathrm{YSZ}[0 \overline{1}$ 1], both of which correspond to a lattice mismatch of $17.2 \%\left(6.02 \AA\right.$ for $\mathrm{Cu}_{2} \mathrm{O}$ film and 7.27 $\AA$ for YSZ substrate). The domains $\boldsymbol{B}$ and $\boldsymbol{b}$ grow in principle with their [1111] orientation parallel to YSZ [011] and [011], and the domains $\boldsymbol{C}$ and $\boldsymbol{c}$ grow with their [111] orientation parallel to YSZ [011] and [011], respectively. However, due to the existence of multiple domains and therefore the possible interaction and stress among them, the above-mentioned parallel relationships are not strict with a deviation of $0.9^{\circ}$ for all the four domains as deduced from Fig. 2 (a) and (b). These four domains grow with a lattice mismatch of $1.5 \%$ between $\mathrm{Cu}_{2} \mathrm{O}<111>(7.38 \AA)$ and $\mathrm{YSZ}<011>(7.27$ A). 

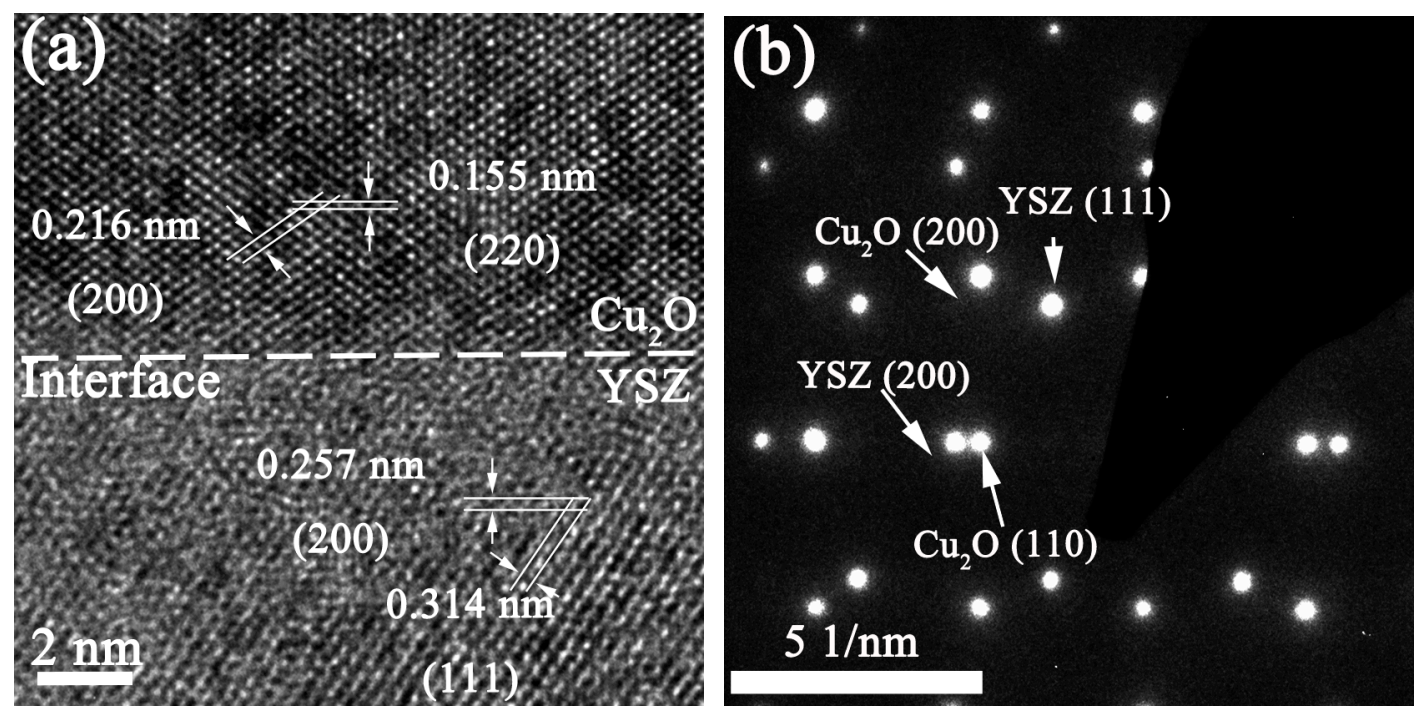

Fig. 3. (a) Cross-sectional HRTEM and (b) SAED micrographs of the film-substrate interface for the sample grown at $0.09 \mathrm{~Pa}$.

The heterostructure of the sample grown at $0.09 \mathrm{~Pa}$ was further studied using the cross-sectional TEM measurements. The HRTEM and SAED micrographs of the interface between the $\mathrm{Cu}_{2} \mathrm{O}$ film and $\mathrm{YSZ}$ substrate are shown in Fig. 3(a) and (b), respectively. The incident electron beam was parallel to the [011] direction of the YSZ substrate. From Fig. 3(a), the uniform and ordered crystal lattice arrays of both the $\mathrm{Cu}_{2} \mathrm{O}$ film and YSZ substrate with a clean and sharp interface inbetween can be observed clearly. The as-marked spacings of the lattice planes for the $\mathrm{Cu}_{2} \mathrm{O}$ film are about 0.155 and $0.216 \mathrm{~nm}$, corresponding to $\mathrm{Cu}_{2} \mathrm{O}$ (220) and (200) planes, respectively, with a standard angular separation of $45^{\circ}$. For the substrate, the as-marked interplane spacings are consistent with YSZ (111) and (200) planes, respectively. From the SAED pattern as shown in Fig. 3(b), the $\mathrm{Cu}_{2} \mathrm{O}$ (200), $\mathrm{Cu}_{2} \mathrm{O}$ (110), YSZ (200) and YSZ (111) diffraction spots are clearly observed, indicating the good crystallinity of this sample area. From the HRTEM and SAED analyses, the 
epitaxial relationship between $\mathrm{Cu}_{2} \mathrm{O}$ film and $\mathrm{YSZ}$ substrate can be deduced as $\mathrm{Cu}_{2} \mathrm{O}$ (110)//YSZ (100) with $\mathrm{Cu}_{2} \mathrm{O}$ [001]//YSZ [011], corresponding to the domain marked as $\boldsymbol{a}$ in Fig. 2(c).

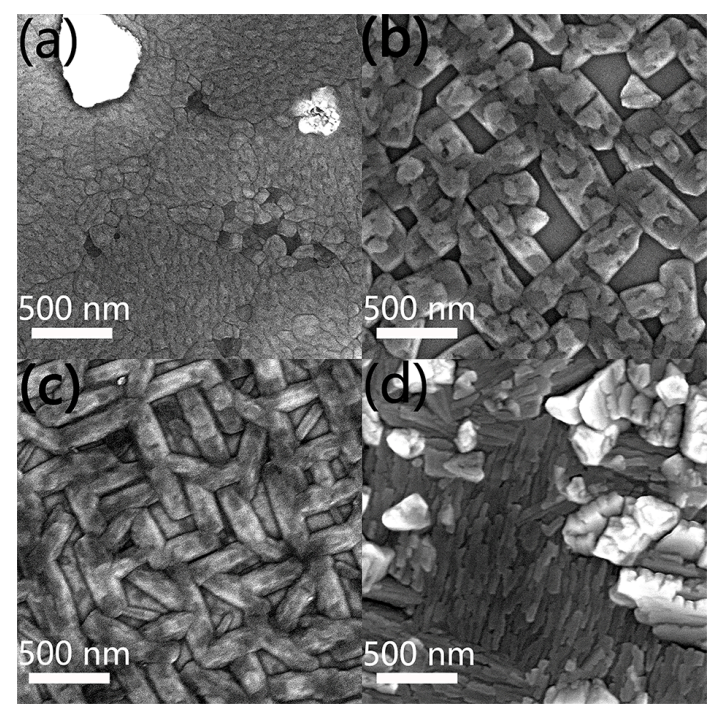

Fig. 4. Plan view SEM micrographs of the copper oxide films grown under the oxygen pressures

$$
\text { of (a) } 0.02 \text {, (b) } 0.06 \text {, (c) } 0.09 \text { and (d) } 0.12 \mathrm{~Pa} \text {. }
$$

The plan view SEM images of copper oxide films deposited under the oxygen pressures of 0.02, 0.06, 0.09 and $0.12 \mathrm{~Pa}$ are shown in Fig. 4(a), (b), (c) and (d), respectively. From Fig. 4(a), submicron particles can be seen on the film surface of the sample prepared at $0.02 \mathrm{~Pa}$, in which metallic $\mathrm{Cu}$ is assumed to act as a catalyst of the growth and mainly exists at the surface of the particles [27]. In Fig. 4(b) and (c), crosswise arranged islands are observed for the films prepared at 0.06 and $0.09 \mathrm{~Pa}$, which are consistent with the existence of multiple domains inside the films. A more compact surface with regularly-shaped islands and well-defined boundaries are observed for the film grown at $0.09 \mathrm{~Pa}$, which is in agreement with the best 
crystallinity of this sample. For the film deposited under $0.12 \mathrm{~Pa}$ as shown in Fig. 4(d), irregular and ill-defined grains are observed due to the mixed phase and degraded crystallinity of this film as revealed from the XRD result. The SEM results demonstrate obviously that the film morphology and crystallinity are strongly influenced by the oxygen pressure, which are in accordance with the XRD analyses.

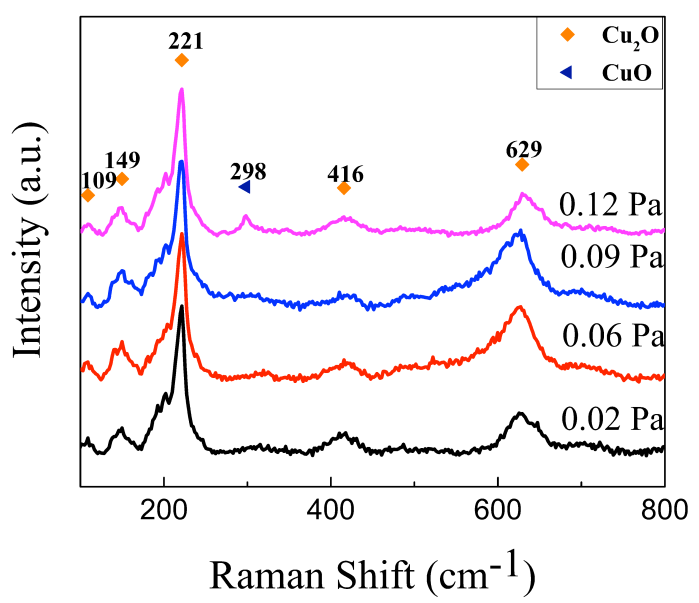

Fig. 5. Raman spectra of copper oxide films grown under different oxygen pressures.

Raman spectra of the as-prepared copper oxide films in the range of $100-800 \mathrm{~cm}^{-1}$ are shown in Fig. 5. The Raman frequencies at 109, 149, 221, 416 and $629 \mathrm{~cm}^{-1}$ were observed for the 0.02-0.09 Pa-deposited samples. The phonon modes at 109 and 149 $\mathrm{cm}^{-1}$ are an inactive Raman mode $\Gamma_{12}^{-}$and an infrared mode $\Gamma_{15}^{-(1)}(\mathrm{LO})$ in $\mathrm{Cu}_{2} \mathrm{O}$ crystal $[28,29]$, respectively. The most intense peak at $221 \mathrm{~cm}^{-1}$ is the second order overtone of $\mathrm{Cu}_{2} \mathrm{O}$, corresponding to $2 \Gamma_{12}^{-}$mode $[28,29]$. The other two peaks at 416 and $629 \mathrm{~cm}^{-1}$ are referred to one fourth order overtone $4 \Gamma_{12}^{-}$and one red allowed mode $\Gamma_{15}^{-(2)}$ (TO) [29], respectively. For the sample grown at 0.02 , the presence of $\mathrm{Cu}$ particles could not be ascertained from $\mu \mathrm{RS}$ due to instrumental limitations for metals 
because they can exhibit surface plasmon resonance (SPR). For metals, local SPR is responsible for field enhancement and therefore leads to surface-enhanced processes, which are only visible using surface enhanced Raman spectroscopy that is helpful for characterizing metallic samples [28]. With the increase of $\mathrm{P}_{\mathrm{O}_{2}}$ to 0.06 and $0.09 \mathrm{~Pa}$, only the peaks at $109,149,221,416$ and $629 \mathrm{~cm}^{-1}$ could be detected, indicating the pure phase $\mathrm{Cu}_{2} \mathrm{O}$ is obtained. Furthermore, the sharp defined mode $2 \Gamma_{12}^{-}$demonstrates the high crystal quality of the samples. As the $\mathrm{P}_{\mathrm{O}_{2}}$ increases further to $0.12 \mathrm{~Pa}$, phonon mode at $298 \mathrm{~cm}^{-1}$ corresponding to the $\mathrm{A}_{\mathrm{g}}$ symmetry of $\mathrm{CuO}$ can be observed [30], indicating the presence of $\mathrm{CuO}$. The results of $\mu \mathrm{RS}$ analyses also correspond very well with the X-ray diffraction results.
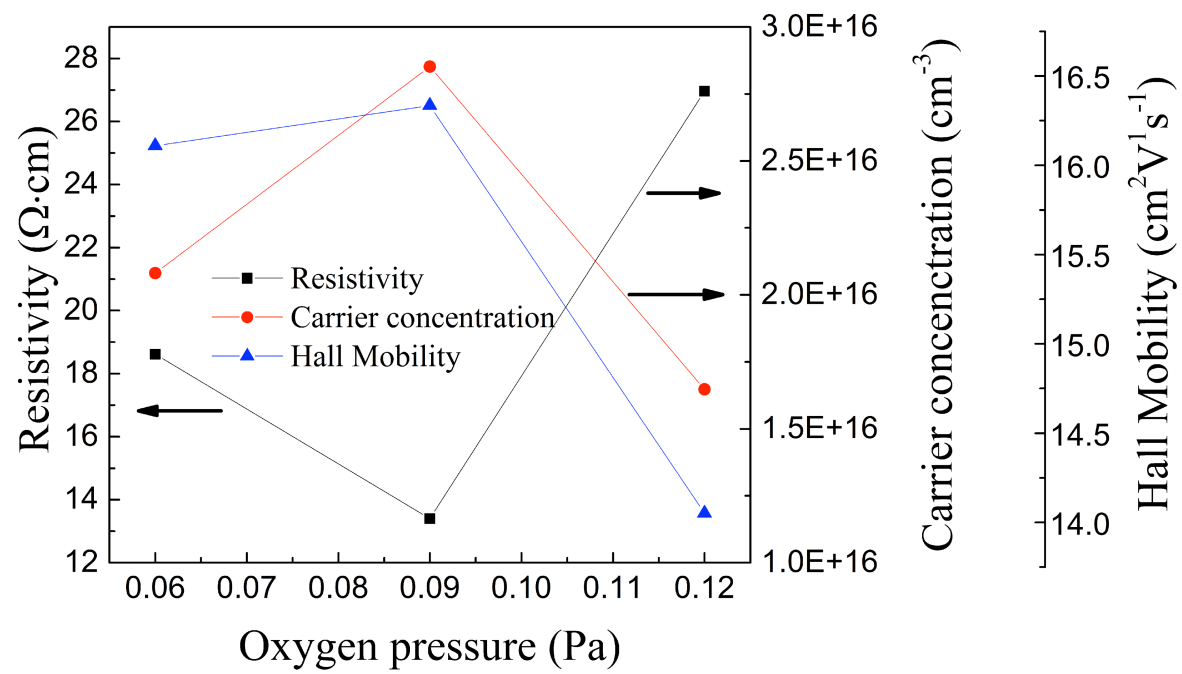

Fig. 6. Dependence of Hall mobility, carrier concentration and resistivity on the oxygen pressure of the copper oxide films.

The Hall mobility, carrier concentration and electrical resistivity of the copper oxide films as a function of oxygen pressure are shown in Fig. 6. The film prepared 
under the $\mathrm{P}_{\mathrm{O}_{2}}$ of $0.02 \mathrm{~Pa}$ is insulating probably due to the compensation of holes caused by the existence of metallic $\mathrm{Cu}$. During the measurement, the p-type conductivity was observed for the rest of the samples as shown in Fig. 5. The carrier concentration initially increases from $2.08 \times 10^{16}$ to $2.85 \times 10^{16} \mathrm{~cm}^{-3}$ with the increase of $\mathrm{P}_{\mathrm{O}_{2}}$ from 0.06 to $0.09 \mathrm{~Pa}$ and then decreases to $1.65 \times 10^{16} \mathrm{~cm}^{-3}$ at $0.12 \mathrm{~Pa}$. The Hall mobility also initially increases from 16.1 to $16.3 \mathrm{~cm}^{2} \cdot \mathrm{v}^{-1} \cdot \mathrm{s}^{-1}$ with the increase of $\mathrm{P}_{\mathrm{O}_{2}}$ from 0.06 to $0.09 \mathrm{~Pa}$ and then decreases to $14.1 \mathrm{~cm}^{2} \cdot \mathrm{v}^{-1} \cdot \mathrm{s}^{-1}$ under the $\mathrm{P}_{\mathrm{O}_{2}}$ of $0.12 \mathrm{~Pa}$. Correspondingly, the resistivity initially decreases and then increases as the $\mathrm{P}_{\mathrm{O}_{2}}$ increases, with a minimum value of $13.4 \Omega \cdot \mathrm{cm}$ obtained at $0.09 \mathrm{~Pa}$. This resistivity is also the lowest value reported so far for the pulsed laser deposited $\mathrm{Cu}_{2} \mathrm{O}$ thin films [16-18]. $\mathrm{Cu}_{2} \mathrm{O}$ films with such low resistivity and high Hall mobility are quite suitable to be used in photovoltaic devices. It is well-known that the p-type conductivity of $\mathrm{Cu}_{2} \mathrm{O}$ is due to the $\mathrm{Cu}$ vacancies $[9,15]$. The initial increases of the Hall mobility and carrier concentration are mainly due to the improvement of crystallinity and increased number of $\mathrm{Cu}$ vacancies, respectively. With further increase of $\mathrm{P}_{\mathrm{O} 2}$ to $0.12 \mathrm{~Pa}$, the $\mathrm{CuO}$ phase is formed leading to the decrease of $\mathrm{Cu}$ vacancies and therefore the decrease of carrier concentration. Meanwhile, the Hall mobility also deceases probably due to the degraded film crystallinity. 

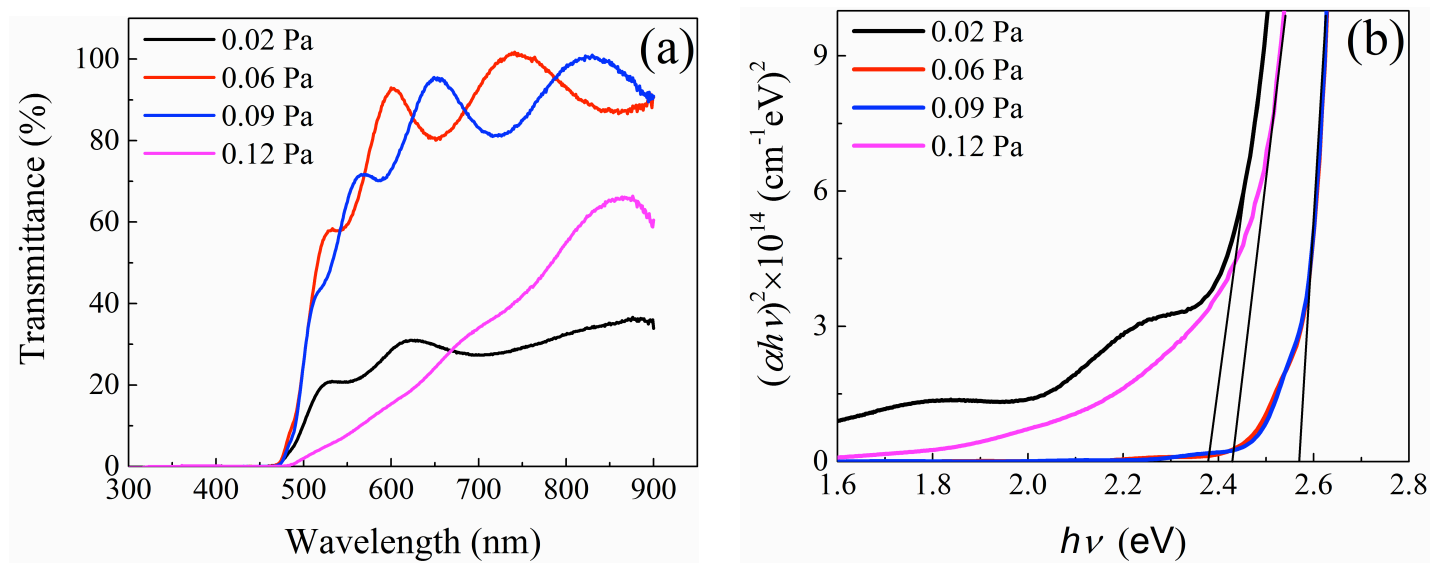

Fig. 7. (a) Transmittance spectra and (b) the plots of $(\alpha h v)^{2}$ versus $h v$ for the copper oxide films prepared under different oxygen pressures.

Fig. 7(a) shows the optical transmittance spectra of the copper oxide films as a function of oxygen pressure in the wavelength range of 300-900 nm. The film prepared at the $\mathrm{P}_{\mathrm{O}_{2}}$ of $0.02 \mathrm{~Pa}$ presents feeble transmittance due to the existence of opaque metallic copper in it. As the $\mathrm{P}_{\mathrm{O}_{2}}$ increases to 0.06 and $0.09 \mathrm{~Pa}$, benefiting from the large band gap of $\mathrm{Cu}_{2} \mathrm{O}(2.0-2.6 \mathrm{eV})$ and improved crystallinity, much higher transmittance is obtained for these films. With the further increase of $\mathrm{P}_{\mathrm{O}_{2}}$, the transmittance of the film decreases again, which is due to the presence of $\mathrm{CuO}$ $(1.2-2.0 \mathrm{eV})$ and degraded crystallinity [31]. A distinct difference between the optical absorption edges can also be seen. The pure $\mathrm{Cu}_{2} \mathrm{O}$ films exhibit sharper absorption edges than the films having impurity phases. As a direct-band gap semiconductor, the optical band gap of $\mathrm{Cu}_{2} \mathrm{O}$ can be estimated by $(\alpha h v)^{2}=A\left(h v-E_{g}\right)$ [32], where $\alpha$ is the absorption coefficient, $A$ is a constant, $h$ is the Planck constant, $v$ is the frequency and $E_{g}$ is the optical energy band gap. The absorption coefficient $\alpha$ is calculated from the transmittance (T) and thickness (d) of the film by using the 
equation of $\alpha=\frac{1}{d} \ln \left(\frac{1}{T}\right)$ [33]. Therefore, the $E_{g}$ could be determined by plotting $(\alpha h v)^{2}$ vs. $h v$ and then extrapolating the straight-line portion of this plot to the energy axis. As shown in Fig. 7(b), the optical band gaps of the copper oxide films deposited at $0.02,0.06,0.09$ and $0.12 \mathrm{~Pa}$ are about $2.37,2.57,2.57$ and $2.43 \mathrm{eV}$, respectively. Similar values and variation tendency of $E_{g}$ were also observed in other reports [5, 34].

\section{Conclusions}

In summary, the copper oxide thin films were prepared on YSZ (100) substrates by PLD and the effect of oxygen pressure during deposition on the structural, morphological, electrical and optical properties of the films was studied. With the increase of oxygen pressure from 0.02 to $0.12 \mathrm{~Pa}$, transitions from mixed phase of $\mathrm{Cu}_{2} \mathrm{O}$ and $\mathrm{Cu}$ to pure $\mathrm{Cu}_{2} \mathrm{O}$ then to mixed phase of $\mathrm{Cu}_{2} \mathrm{O}$ and $\mathrm{CuO}$ were observed. The film prepared at $0.09 \mathrm{~Pa}$ had the best crystallinity with an out-of-plane epitaxial relationship of $\mathrm{Cu}_{2} \mathrm{O}$ (110)//YSZ (100). Six different kinds of domain structure were observed and the corresponding in-plane epitaxial relationships were proposed for the 0.09 Pa-deposited sample. An obvious change of film surface morphology was observed with oxygen pressure. The lowest resistivity of $13.4 \Omega \cdot \mathrm{cm}$ with a carrier concentration of $2.85 \times 10^{16} \mathrm{~cm}^{-3}$ and a Hall mobility of $16.3 \mathrm{~cm} \cdot \mathrm{v}^{-1} \cdot \mathrm{s}^{-1}$ were obtained for the film deposited at $0.09 \mathrm{~Pa}$. The transmittance of the films was strongly influenced by oxygen pressure and the optical band gap varied between 2.37 and $2.57 \mathrm{eV}$. The high quality $\mathrm{Cu}_{2} \mathrm{O}$ epitaxial films with low resistivity and high mobility 
obtained in our study may have promising applications in different fields such as photovoltaic devices and thin film transistors.

\section{References}

[1] T. Mahalingam, J.S.P. Chitra, S. Rajendran, M. Jayachandran, M.J. Chockalingam, Galvanostatic deposition and characterization of cuprous oxide thin films, J. Cryst. Growth 216 (2000) 304-310.

[2] Huang, Q.; Li, J.; Bi, X. The Improvement of Hole Transport property and optical band gap for amorphous $\mathrm{Cu}_{2} \mathrm{O}$ films. J. Alloys Compd. 647 (2015) 585-589.

[3] T.G. Kim, H.-B. Oh, H. Ryu, W.-J. Lee, The study of post annealing effect on $\mathrm{Cu}_{2} \mathrm{O}$ thin-films by electrochemical deposition for photoelectrochemical applications, J. Alloys Compd. 612 (2014) 74-79.

[4] J.F. Pierson, A. Thobor-Keck, A. Billard, Cuprite, paramelaconite and tenorite films deposited by reactive magnetron sputtering, Appl. Surf. Sci. 210 (2003) 359-367.

[5] B. Balamurugan, B.R. Mehta, Optical and structural properties of nanocrystalline copper oxide thin films prepared by activated reactive evaporation, Thin Solid Films 396 (2001) 90-96.

[6] E. Fortin, F.L. Weichman, Hall effect and electrical conductivity of $\mathrm{Cu}_{2} \mathrm{O}$ monocrystals, Can. J. Phys. 44 (1966) 1551-\&.

[7] H. Jing, Z. Yu, L. Li, Antibacterial properties and corrosion resistance of $\mathrm{Cu}$ and $\mathrm{Ag} / \mathrm{Cu}$ porous materials, J. Biomed. Mater. Res., Part A 87A (2008) 33-37.

[8] T. Minami, Y. Nishi, T. Miyata, J.-i. Nomoto, High-Efficiency Oxide Solar Cells with $\mathrm{ZnO} / \mathrm{Cu}_{2} \mathrm{O}$ Heterojunction Fabricated on Thermally Oxidized $\mathrm{Cu}_{2} \mathrm{O}$ Sheets, Appl. Phys. Express 4 (2011) 062301.

[9] N.G. Elfadill, M.R. Hashim, K.M. Chahrour, S.A. Mohammed, Preparation of p-type Na-doped $\mathrm{Cu}_{2} \mathrm{O}$ by electrodeposition for a p-n homojunction thin film solar cell, Semicond. Sci. Technol. 31 
(2016) 065001.

[10] T. Minami, Y. Nishi, T. Miyata, Heterojunction solar cell with $6 \%$ efficiency based on an n-type aluminum-gallium-xide thin film and p-type sodium-doped $\mathrm{Cu}_{2} \mathrm{O}$ sheet, Appl. Phys. Express 8 (2015) 022301.

[11] L.C. Olsen, F.W. Addis, W. Miller, Expreimental and theoretical-studies of $\mathrm{Cu}_{2} \mathrm{O}$ solar-cells, Sol. Cells 7 (1982) 247-279.

[12] Y. Fu, H. Lei, X. Wang, D. Yan, L. Cao, G. Yao, C. Shen, L. Peng, Y. Zhao, Y. Wang, W. Wu, Fabrication of two domain $\mathrm{Cu}_{2} \mathrm{O}(011)$ films on $\mathrm{MgO}(001)$ by pulsed laser deposition, Appl. Surf. Sci. 273 (2013) 19-23.

[13] Z.Q. Yu, C.M. Wang, M.H. Engelhard, P. Nachimuthu, D.E. McCready, I.V. Lyubinetsky, S. Thevuthasan, Epitaxial growth and microstructure of $\mathrm{Cu}_{2} \mathrm{O}$ nanoparticle/thin films on $\mathrm{SrTiO}_{3}(100)$, Nanotechnology 18 (2007) 115601.

[14] I. Pallecchi, E. Bellingeri, C. Bernini, L. Pellegrino, A.S. Siri, D. Marre, Epitaxial copper oxide thin films deposited on cubic oxide substrates, J. Phys. D: Appl. Phys. 41 (2008) 125407.

[15] G. Kaur, A. Mitra, K.L. Yadav, Influence of oxygen pressure on the growth and physical properties of pulsed laser deposited $\mathrm{Cu}_{2} \mathrm{O}$ thin films, J. Mater. Sci.: Mater. Electron. 26 (2015) 9689-9699.

[16] K. Matsuzaki, K. Nomura, H. Yanagi, T. Kamiya, M. Hirano, H. Hosono, Epitaxial growth of high mobility $\mathrm{Cu}_{2} \mathrm{O}$ thin films and application to p-channel thin film transistor, Appl. Phys. Lett. 93 (2008) 202107.

[17] K. Matsuzaki, K. Nomura, H. Yanagi, T. Kamiya, M. Hirano, H. Hosono, Effects of post-annealing on (110) $\mathrm{Cu}_{2} \mathrm{O}$ epitaxial films and origin of low mobility in $\mathrm{Cu}_{2} \mathrm{O}$ thin-film transistor, Phys. Status Solidi A 206 (2009) 2192-2197. 
[18] F.-Y. Ran, H. Hiramatsu, H. Hosono, T. Kamiya, M. Taniguti, Detection of dead layers and defects in polycrystalline $\mathrm{Cu}_{2} \mathrm{O}$ thin-film transistors by x-ray reflectivity and photoresponse spectroscopy analyses, J. Vac. Sci. Technol., B 33 (2015) 051211.

[19] S. Jeong, E.S. Aydil, Heteroepitaxial growth of $\mathrm{Cu}_{2} \mathrm{O}$ thin film on $\mathrm{ZnO}$ by metal organic chemical vapor deposition, J. Cryst. Growth 311 (2009) 4188-4192.

[20] T. Peng, K. Shen, H. Wu, C. Hu, C. Liu, Room-temperature ferromagnetism and electrical properties of $\mathrm{Cu}_{2} \mathrm{O} / \mathrm{GaN}$ heterostructures, J. Phys. D: Appl. Phys. 43 (2010) 315101.

[21] A. Wagner, H. Scherg-Kurmes, A. Waag, A. Bakin, Vapour phase epitaxy of $\mathrm{Cu}_{2} \mathrm{O}$ on a-plane $\mathrm{Al}_{2} \mathrm{O}_{3}$, in: S. Hildebrandt, M. Cavalleri, L. Herrmann, H. Hopcke, I. Juschak, C.N. DaSilva, A. Pfisterer, I. Stass (Eds.), Physica Status Solidi C: Current Topics in Solid State Physics., Nice, 2013, pp. 1284-1287.

[22] J. Du, S. Gnanarajan, A. Bendavid, Characterization of $\mathrm{MgO}$ substrates for growth of epitaxial YBCO thin films, Supercond. Sci. Technol. 18 (2005) 1035-1041.

[23] X.Q. Cao, R. Vassen, D. Stoever, Ceramic materials for thermal barrier coatings, J. Eur. Ceram. Soc. 24 (2004) 1-10.

[24] D.R. Clarke, S.R. Phillpot, Thermal barrier coating materials, Mater. Today 8 (2005) 22-29.

[25] K.W. Schlichting, N.P. Padture, P.G. Klemens, Thermal conductivity of dense and porous yttria-stabilized zirconia, J. Mater. Sci. 36 (2001) 3003-3010.

[26] S.B. Ogale, P.G. Bilurkar, N. Mate, S.M. Kanetkar, N. Parikh, B. Patnaik, Deposition of copper-oxide thin-films on different substrates by pulsed excimer laser ablation, J. Appl. Phys. 72 (1992) 3765-3769.

[27] V.X. Hien, J.-L. You, K.-M. Jo, S.-Y. Kim, J.-H. Lee, J.-J. Kim, Y.-W. Heo, Synthesis of 
submicron-sized rods and trees of $\mathrm{Cu}_{2} \mathrm{O}$ by radio-frequency magnetron sputtering, Vacuum 111 (2015) $60-67$.

[28] A. Sahai, N. Goswami, S.D. Kaushik, S. Tripathi, $\mathrm{Cu} / \mathrm{Cu}_{2} \mathrm{O} / \mathrm{CuO}$ nanoparticles: Novel synthesis by exploding wire technique and extensive characterization, Appl. Surf. Sci. 390 (2016) 974-983.

[29] H. Solache-Carranco, G. Juarez-Diaz, M. Galvan-Arellano, J. Martinez-Juarez, G. Romero-Paredes R, R. Pena-Sierra, Raman scattering and photoluminescence studies on $\mathrm{Cu}_{2} \mathrm{O}$, 5th International Conference on Electrical Engineering, Computing Science and Automatic Control, IEEE., Mexico City, 2008, pp. 421-424.

[30] M.H. Chou, S.B. Liu, C.Y. Huang, S.Y. Wu, C.L. Cheng, Confocal Raman spectroscopic mapping studies on a single $\mathrm{CuO}$ nanowire, Appl. Surf. Sci. 254 (2008) 7539-7543.

[31] A.H. Jayatissa, K. Guo, A.C. Jayasuriya, Fabrication of cuprous and cupric oxide thin films by heat treatment, Appl. Surf. Sci. 255 (2009) 9474-9479.

[32] A.A. Ogwu, E. Bouquerel, O. Ademosu, S. Moh, E. Crossan, F. Placido, An investigation of the surface energy and optical transmittance of copper oxide thin films prepared by reactive magnetron sputtering, Acta Mater. 53 (2005) 5151-5159.

[33] M.R. Johan, M.S.M. Suan, N.L. Hawari, H.A. Ching, Annealing Effects on the Properties of Copper Oxide Thin Films Prepared by Chemical Deposition, International Journal of Electrochemical Science 6 (2011) 6094-6104.

[34] M.H.P. Reddy, J.F. Pierson, S. Uthanna, Structural, surface morphological, and optical properties of nanocrystalline $\mathrm{Cu}_{2} \mathrm{O}$ and $\mathrm{CuO}$ films formed by $\mathrm{RF}$ magnetron sputtering: Oxygen partial pressure effect, Phys. Status Solidi A 209 (2012) 1279-1286. 
Figure Captions:

Fig. 1 XRD patterns of copper oxide films grown on YSZ (100) substrates under different oxygen pressures.

Fig. 2. XRD patterns of off-specular $\Phi$-scan for the (a) $\mathrm{Cu}_{2} \mathrm{O}\{111\}$ and (b) $\mathrm{YSZ}\{111\}$ planes of the sample grown under $\mathrm{P}_{\mathrm{O}_{2}}$ of $0.09 \mathrm{~Pa}$. (c) Proposed in-plane epitaxial relationships between the $\mathrm{Cu}_{2} \mathrm{O}$ film and $\mathrm{YSZ}$ substrate.

Fig. 3. (a) Cross-sectional HRTEM and (b) SAED micrographs of the film-substrate interface for the sample grown at $0.09 \mathrm{~Pa}$.

Fig. 4. Plan view SEM micrographs of the copper oxide films grown under the oxygen pressures of (a) 0.02, (b) 0.06, (c) 0.09 and (d) $0.12 \mathrm{~Pa}$.

Fig. 5. Raman spectra of copper oxide films grown under different oxygen pressures.

Fig. 6. Dependence of Hall mobility, carrier concentration and resistivity on the oxygen pressure of the copper oxide films.

Fig. 7. (a) Transmittance spectra and (b) the plots of $(\alpha h v)^{2}$ versus $h v$ for the copper oxide films prepared under different oxygen pressures. 